\title{
AUDIO GAMES AS A LUDIC TOOL FOR VISUALLY IMPAIRED STUDENTS IN ELEMENTARY SCHOOL
}

\section{${ }^{1}$ Felipe Nascimento Nogueira da Silva, ${ }^{1}$ Rafael Santos de Souza, ${ }^{1}$ Bruno Pereira Gonçalves, ${ }^{1}$ Manfrine silva santos, ${ }^{1}$ Rilmar Pereira Gomes, ${ }^{1}$ Jean Mark Lobo de Oliveira and ${ }^{2}$ David Barbosa de Alencar}

\author{
${ }^{1}$ Academic department, University Center FAMETRO, Amazon-Brazil \\ ${ }^{2}$ Institute of Technology and Education Galileo of Amazon (ITEGAM), Brazil
}

\section{ARTICLE INFO}

Article History:

Received $07^{\text {th }}$ March, 2020

Received in revised form

$06^{\text {th }}$ April, 2020

Accepted $17^{\text {th }}$ May, 2020

Published online $29^{\text {th }}$ June, 2020

\section{Key Words:}

Audio games; Visual impairment; Education; Ludic; Equality; Inclusion; Teaching.

*Corresponding author: David Barbosa de Alencar,

\begin{abstract}
Today there are few educational institutions that carry out activities that promote entertainment, fun and the inclusion of visually impaired people in the educational environment. In this article it is presented a playful form of teaching in which there will be a greater social inclusion for the visually impaired in an institutional environment. In view of the practicality of intuitive games to support the learning of the visually impaired, the objective is to demonstrate an electronic game tool not yet well known by the general public: audio games, in order to show that games with distinct characteristics were adopted to check which will be more promising for a visually impaired person in support of learning. With questionnaire methods in search of divergent opinions, description of concepts, divergences and difficulties, demonstration of possible audio games that may be included in the teaching dynamics and various texts and articles on the subject, it is possible to conclude that there is little knowledge of the existence of audio games and, along with that, the inequality in the educational system, given the lack of social inclusion in relation to the visually impaired in ludic teaching activities. Therefore, it is necessary to create and implement greater activities aiming equality, inclusion, participation and education for all during elementary school, a phase of great moral and educational development.
\end{abstract}

Copyright (C) 2020, Felipe Nascimento Nogueira da Silva et al. This is an open access article distributed under the Creative Commons Attribution License, which permits unrestricted use, distribution, and reproduction in any medium, provided the original work is properly cited.

Citation: Felipe Nascimento Nogueira da Silva, Rafael Santos de Souza, Bruno Pereira Gonçalves et al. "Audio Games As A Ludic Tool For Visually Impaired Students In Elementary School”, International Journal of Development Research, 10, (06), 37051-37056.

\section{INTRODUCTION}

In Brazil there are more than 6.5 million people with some type of visual impairment, according to the last census of the Brazilian Institute of Geography and Statistics (IBGE), 582 thousand Brazilians are completely blind and 6 million have low vision, there is no difference in children, since in Brazil 33 thousand children are blinded by preventable eye diseases according to the Brazilian Council of Ophthalmology. According to the International Blindness Prevention Agency, an organ linked to the World Health Organization (WHO), at least 100 thousand Brazilian children have some type of visual impairment. Approximately 15 million school-age children show some refractive error capable of generating learning problems, low selfesteem and difficulties in social inclusion. Playful activity has the ability to assist a child in developing his self-esteem, ability to social interaction and to concentration, which becomes a great help for their development in the classroom, in addition to their way of communicating and expressing themselves, leaving the child free to express themselves and have fun, without imposing any rivalry among the members who participate, we can exemplify as a playful activity the puppet theater, which can help the student to express himself among other members, including the participation of children with visual impairments. Due to the high presence of technology in our social environment, it is necessary to include anyone at the use of computer, smartphone or another technological device that we can see on a daily basis. Also, the growing wave of video games as a form of entertainment in everyday life, for decades have been bringing more and more power in hardware and software. Thus, exploring the feasibility and the need to include people with visual impairments, there was the creation of video games with this purpose, called audio games. Video games that enable the gameplay of people with visual impairments (audio games) use sound resources to guide the player's actions. Through sound, the user can know what to do and where to go, a characteristic that makes it accessible for blind or who have some kind of visual limitation. Taking into account the inclusion of people with visual problems, we can see a viability in the creation of audio games for people with this need, and with the appearance of audio games in the market, this entertainment tool can help in adapting the system to aid in education, job market, personal day to day and etc. Depending on the developer's creativity, even existing games can be adapted, as well as the classic "Minesweeper", it has an 
accessible version for the blind in which the player uses the arrow keys to move. Moreover, the one-dimensional sound effect indicates the available spaces, the ones that have already been opened, the edge of the board, and the mine. This sound guidance can also come from a narrator, who indicates what needs to be done or offers a narrative with movement options for the player to choose.

\section{MATERIALS AND METHODS}

Methodologies: It was approached through a Google Forms questionnaire, with questions formulated on the subject in question, involving the topics mentioned in this article, such as audio games and visual impairment in elementary school, with people chosen at random to answer the questions and thus quantify opinions and information for the determined study, generating statistics and graphs. A study was carried out on audio games at national level as well as on the visual impairment that is included in the middle of elementary education, in order to analyze the already existing audio games tool or the feasibility of its use in the educational area of elementary education, and so study the use of audio games for the visually impaired correlate existence in the children's educational area. The research was carried out on sites related to technological areas to obtain examples of software created with the purpose of performing works related to audio games for visually impaired people, as well as looking for examples of system implementation in children's education for playful activities, or examples of testing audio games, and also the existing difficulty in children's visual impairment. Through this methodology the study of articles and books related to audio games will be carried out, as well as research related to Brazilian elementary education and informal documents from game developers with the same purpose defined in the article's theme.

Materials: Questionnaire with 16 questions, made by the Google Forms application for greater opinions and discussions on the subject. Research and articles by third parties on the subject through digital platforms. Games that are adapted for audio games and that can become a playful way of teaching

\section{BIBLIOGRAPHIC REVIEW}

Ludic Concept: The ludic concept refers to everything that is related to entertainment activities, whether with toys or games. The word ludic is an adjective that comes from the Latin ludos, an expression related to ways of recreation, that is, ways to promote fun and entertainment, including that the interaction in the children's environment is widely used in a ludic way since the act of playing and having fun is considered the main channel of communication between teachers and students through playful activities, that are present in Brazilian elementary schools, which aim at the learning of the ludic individual through toys, actions and games that take pleasure when being practiced freely without the need for competition between the participants. Thus, norms or rules are totally dispensable, considering that the ludic activity does not propose the intention of any type of dispute between individuals. The ludic individual is the one who has the ability to express, feel or create with the contagious feeling of joy and the state of ecstasy that activities provide him, it is a plunge into the ludic, or even the ludic in action. In the act of playing, the child explores the world and its possibilities at the same time that it is inserted in it, spontaneously and playfully developing their cognitive, motor and affective abilities. The need for play among children is of great importance as a ludic activity, according to Kishimoto (2011).
The playful text or discourse seeks the way to condition the individual, intending only the dialogical part, thus modeling its interpersonal part. This type of text is produced by pure pleasure brought to the practitioner, thus serving as a resource to draw people's attention. As an example of playful activities, we can mention the child's speech learning process in a real exercise in communicating, thus playing with his speech. Songs and poems are also exampling of playful texts. In the type of playful discourse, there is an interaction between the "I" and "you" in which the two interlocutors dialogue. Thus, we have the confirmation of the playful activity entering the mental capacity of the individual and clearly being considered as an idea of development among the playful individuals of our society.

Learning in Brazilian elementary school: Brazilian elementary school is divided into two groups, Elementary School I and Elementary School II, with a total duration of 9 years and involves the development of children and pre-teens. Elementary education is of great importance for the development of the child in both academic, personal and social terms. At this stage, students begin to learn educational concepts, which are the subjects that will guide them throughout basic education, and they learn to read and write. This literacy process allows studies to become more complex and for children to broaden their worldview. According to the Ministry of Education - MEC, in the early years of elementary school should study children aged 6 to 10 years, being that the student's literacy must occur in the 1 st year of elementary school, that is, at the age of six he must learn to read and write. Elementary Education II being a continuation of Elementary Education I offers a greater complexity, which allows the child to resume the learning acquired in Elementary Education I and deepen his knowledge, thus increasing his repertoire. Brazil occupies the 53rd place in education, among 65 evaluated countries (PISA). Even with the social program that encouraged the enrollment of $98 \%$ of children between 6 and 12 years old, 731 thousand children are still out of school (IBGE). Functional illiteracy among people between 15 and 64 years old was registered in $28 \%$ in 2009 (IBOPE); 34\% of students who reach the 5 th year of schooling are still unable to read (Everyone for Education); 20\% of young people who complete elementary school, and who live in large cities, do not dominate the use of reading and writing (Everyone for Education) according to Eliane da Costa Bruini (2020). The learning method in elementary education in schools in Brazil consists of different techniques used by teachers that assist the development of the child, with the aim of helping the student to build his knowledge and helping him to acquire and fix the content taught in the classroom. The teacher has the duty to pass on these techniques very well to the designated students, he must be very careful in planning his techniques and also in his practice, because when choosing one, it must be analyzed if it is suitable for that content and if it will be able to reach your students in a positive way, the age of the students and what grade they are in should also be considered. In addition, it is important for the teacher to have sufficient knowledge of his students for the best application of learning. There are different strategies that apply in the teaching/learning of the Brazilian elementary education system, among them the ludic strategy, applied in Brazilian elementary education as a strategy that consists of using fun and games to fix the content. In these classes, moments of relaxation and happiness are observed, which relieve tension and favor learning. Therefore, we can observe the importance of playful activity and how it has been 
applied for a long time being successful as a teaching tool in our education. The child is a being in creation, each act is an opportunity for him to explore and take possession of himself, or, to put it better, for each extent the expansion of himself. And this operation, carries it out vehemently, with faith: a continuous game. The importance stems from conquest to conquest, an incessant vibration according to Maria Montessori (2016).

Visual impairment in children: It is known that $23 \%$ of the general population has disabilities and it is estimated that at least $7.5 \%$ of Brazilian children (up to 14 years of age) have a diagnosed disability, according to a 2010 IBGE survey. As we are aware of the significance of elementary education for child development, we can observe an expressive and signaling percentage demonstrated by IBGE, that lead us to realize the size of the challenge that a child with a disability can have when entering at elementary school, with this, we can open our thinking in relation to concepts such as empathy, when we realize the difficulty that is faced by this percentage of students when entering at a public education system in Brazil, which will be too important for their social and professional progress. We must also highlight the concept of law, directing to the circle, since it is essential to improve our inclusion in society because every child has the right to education, according to the Brazilian Inclusion Law (LBI - 13.146 / 2015), established in 2015 - after TWELVE years in progress. The Declaration of Salamanca (1994) was of great importance because it is a document prepared at the world conference on special education in Salamanca, Spain, with the aim of clarifying basic guidelines for the formulation and reform of educational policies and systems according to the movement of social inclusion. The Salamanca Declaration strengthened the idea of special educational needs, encompassing all children who are failing to thrive in school, for whatever reason. Thus, the idea of "special educational needs" now includes, in addition to children with disabilities, those who are experiencing temporary or permanent difficulties at school. Among the problems that visual impairment can generate is the problem of recognizing the environment, which consists of a lack of knowledge of the area around, such as at home, for example, as well as in a school environment, making learning difficult, taking the child to be prone to falls and crashes, thus taking some time to get used to the place. The problem in the use of computers can be a complication, since informatics has been an educational issue widely used today due to the growth in the use of computers in the educational and professional sector. We can highlight the work of ACIG that develop activities that enable inclusion in leisure. We can also mention the problem related to reading and writing, because in a visually impaired child we may have specific problems when teaching him, for that, some methods are used for the visually impaired people to read. On April 8, the National Day of the Braille System is celebrated. It is a system formed by tactile codes that make it possible for people with visual impairments to read and write. The Ministry of Education (MEC) works every day to make Brazilian education more inclusive. One of the main actions to promote accessibility is the National Accessible Textbook Program, which destines books written in braille for blind or low vision students. From 2019, textbooks started to be printed in braille and enlarged letters in Portuguese. Thus, blind students receive the same books that the rest of the students in the class. That allows both families and teachers to follow what the student who uses braille is reading, according to the secretary of Specialized Education Modalities, Ilda Peliz (2018).

Audio games as a ludic tool for visually impaired students in elementary school: The world of audio games works in a relatively hidden way in the digital games community, taking into account the number of people who do not have the knowledge of technology, which is present in our country due to the interest of developers in adapting the games in an adjustable way to the visually impaired, either for their entertainment or other purposes, such as educational, in the way that digital games help exercise specific parts of the brain, as well as bringing entertainment in an immersive world of fun and imagination. The game Blind Legend tells the story of a knight who lost his sight after having his wife kidnapped, the game was produced by the French company DOWINO. Thus, expanding the community of players to the visually impaired public inducing people to the concept of social inclusion and the right of people with disabilities.

In Brazilian elementary school, games such as puzzle and bingo contribute to the educational development of children in schools, since they work on the logical reasoning of the participants as well as on the Portuguese language, thus bringing fun and education, uniting the useful to the pleasant with the students as a target audience, making the game somewhat a playful activity, since it aims to contribute to the professional and personal development of the child involved in the game. In the same way a digital game works simulating a virtual environment, surrounded by stories and a communication channel, and most of the time a video game control for the player. Audio games work almost similarly to video games, but the communication between game and player becomes different, since the player does not have the aid of vision, but of the phono receptors and hearing, since the game has sound waves to guide the player, so the audio game becomes a tool of playful activity, since it brings fun in an enjoyable world for the player, bringing inclusion and development. According to a study by the University of Rochester, in the United States, and published in the journal Nature, the act of playing video games increases the selective and visual capacity of the individual, making him faster in decision-making. An example of this is that several companies have resorted to video games and board games in their selection processes, thus being able to check the attention and personality of their candidates.

There is no doubt that video games have managed to create a great impact on our society and a great presence in current technology, bringing entertainment to people of all ages. In children audiences, video games also have a great influence, from the beginning of childhood to the end of it, because in this way the games become a great act of inclusion, seeing that from the creation of a game it is possible to use artifice to grant children with visual impairment the possibility to enjoy this entertainment, thus we can show the example of great game developers that made it possible to include this audience in gaming technology. [8]

Super Mario Bros. Audio Edition: A classic like this was adapted for the use of people with visual impairments. More than an inspiration, this audio game is almost a faithful copy of the Nintendo's game. It follows the same idea, way of playing and still has the same soundtrack and effects to help the new audience. 
Developed by Jaqocon Games, the visually impaired version of Super Mario Bros has a multitude of sound indications that are likely to confuse beginning players. For each situation there is a sound, and to know what each sound means, the game offers a sound guide for the gamer to become familiar with them. Those who still have the map of this game engraved in their memory can do very well, because even without any visual indication, the adaptation tried to be as faithful as possible of the classic game.

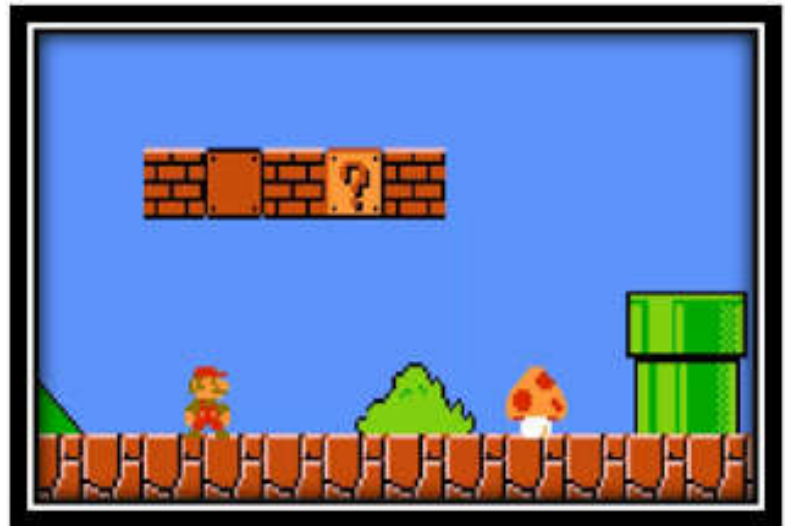

Figure 1 - Illustration of the game Super Mario Bros. Audio Edition Source: techtudo.com.br

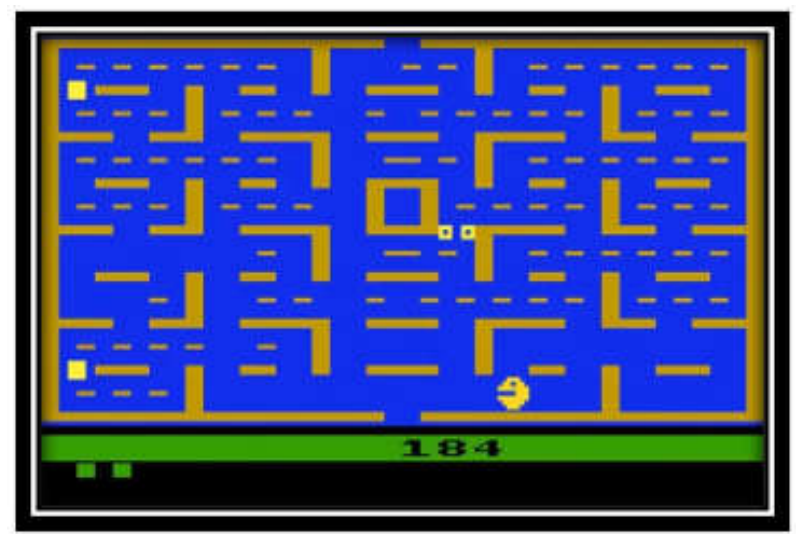

Figure 2 - Illustration of the game Pac-Man Talks Source: www.techtudo.com.br

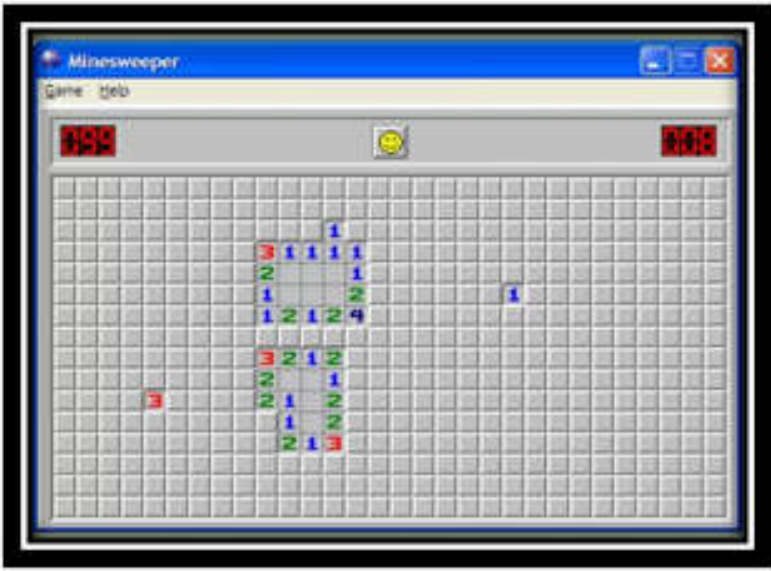

Figure 3 - Illustration of the game Minesweeper Source: www.techtudo.com.br

Pac-Man Talks: Developed by PCS Games, this audio game inspired by Pac-Man follows the same idea as the original, including all the effects and soundtrack so characteristic of the game, thus leaving audio games players inside one of the most famous games ever developed. The objective of the game is the same of the original: to escape the ghosts and collect as many points as possible. To help the player move around the map, the audio game uses a narrator that indicates the possible paths that lie ahead, while the characteristic rising sound of the ghosts indicates that they are getting close to the player.

Mine Buster: Based on a Windows classic, Minesweeper, the audio game developed by GMA Games manages to convey all the apprehension that has when exploring and opening the houses on the board without blowing up a bomb using only mono sound to know what is happening. With three levels of difficulty in which the field has more houses in each one, the adaptation faithfully follows the same principles of the classic game and does not have any visual resources. Its gameplay is intuitive and simple, the player uses the arrow keys to navigate through the houses and the sounds indicate which ones can be explored, which have already been opened and the limit of the board. To help the player know how many bombs he has around him when opening a house, the narrator speaks a number, just as it does in the Windows Minesweeper, which made this same indication showing numbers around the selected location.

A Blind Legend: Being a game more recent than the previous ones, Blind Legend narrates the saga of a knight who lost his sight after having his wife kidnapped, in this game the challenge becomes to cross environments full of dangers such as a labyrinthine and threatening forest, for example. With a narrator who enters at certain times and controlling the character's movements by touching the screen or the mouse, you can lead the knight Edward Blake incarnating his daughter and can even control a sword, which works with corresponding sudden movements of the player. This game brings a more dramatic genre that has also being successful in conventional video games, thus enabling the popularization of other categories of games that can be developed and targeted to the visually impaired audiences.

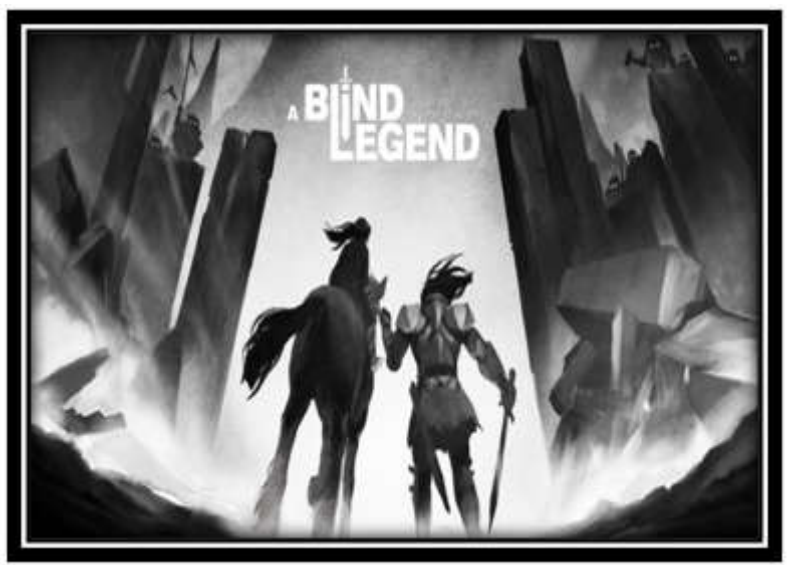

Figure 4 - Illustration of the game Blind Legend Source: jogandoascegas.com.br.

\section{DISCUSSION OF RESULTS}

The work related to the theme of audio games in the context of fundamental education for the visually impaired, has as importance the demonstration of how video games can playfully influence a child in a state of development of his academic and professional features, as well as bringing the emphasis on the concept of inclusion and human rights, seeking to fill the lack of digital games in the educational area, in view of their proof of effectiveness in educational teaching, including audio games, becoming a playful tool for people 
with some type of visual impairment, bringing information related to the existence of difficulties faced by teachers in education and people belonging to the social circle of a visually impaired child.

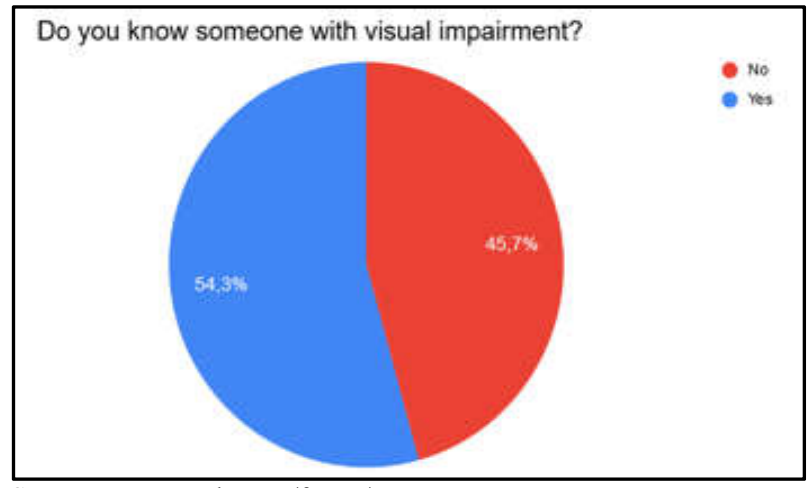

Source: apps.google.com/forms/

\section{Graphic 1. Questionnaire results}

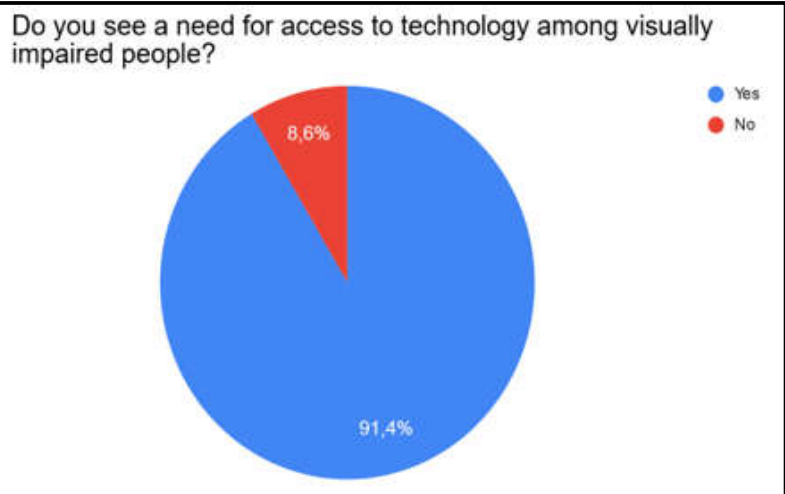

Source: apps.google.com/forms

Graphic 2. Questionnaire results

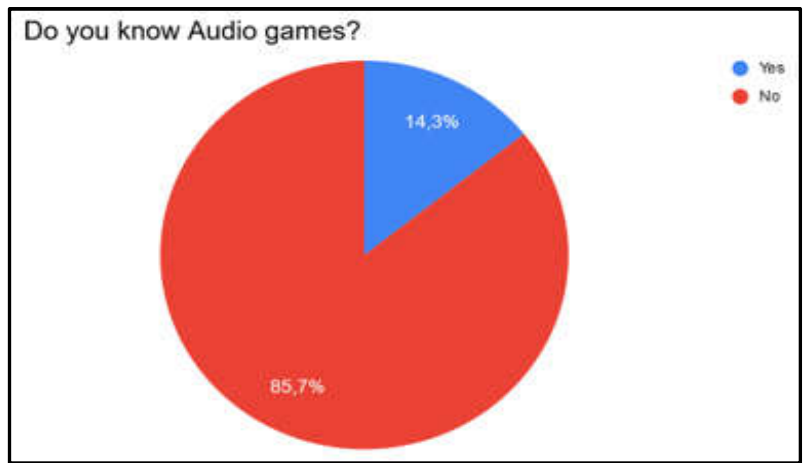

Source: apps.google.com/forms/

Graphic 3. Questionnaire results

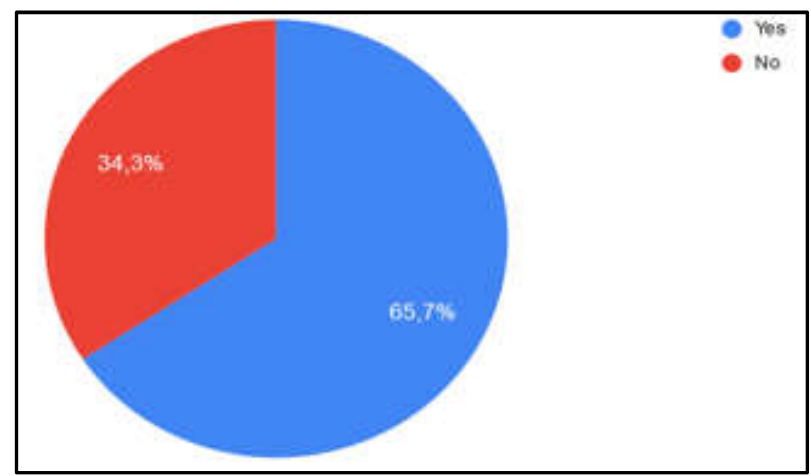

Source: apps.google.com/forms/

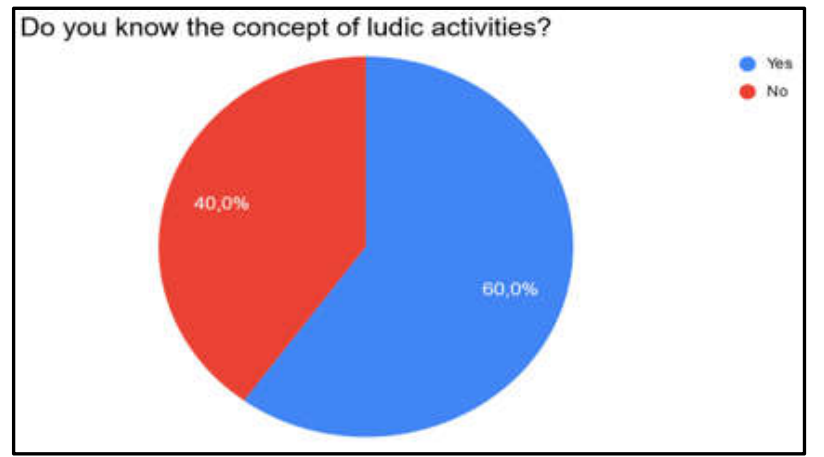

Source: apps.google.com/forms/

Graphic 4. Questionnaire results

Among the individuals questioned, it can be noted the existence of people with visual impairments in the personal circle of most of the people interviewed, it was noted that the existence of people with disabilities of this type in our environment is very normal relating to the disability statistics in our country, we can see the possibility of having a visual impairment individual in our educational environment also identified in research. When relating the existence of a need for technology among the group of visually impaired people, it can be seen that more than $90 \%$ of respondents see this need as valid for the community of people with disabilities, it is in fact visible that there is a great importance and presence of technology in our social environment, including in research presented, so being a viable means of inclusion for these people and thus being able to help in countless ways someone with visual impairment. Thus, we can define the existence of audio games as little known, because a little less than $15 \%$ of those interviewed have the knowledge of what audio games are, despite the existence of famous games with this tool to help the visually impaired, which could be a potential market, in view of the existence of a large public in the national territory. One can also mention the study related to the beneficial side that video games bring to the person who practices it, in view of its possibility of use as a playful tool. However as seen in the research, few people are aware of its existence, of a tool that would be strongly competing in the social inclusion of this public.

We can see a difference not as big as the other surveys in relation to people who have knowledge of playful activities, with $40 \%$ of people who do not have this knowledge, even though they may have already practiced these activities outside the school environment, since it is an activity that is practiced by most people, and that also help in their development. It can be noticed that even with the application of this technique in our Brazilian elementary school, only $60 \%$ of the people interviewed have knowledge about it, greater knowledge of playful activities would be of great importance for one of the main application techniques for the development of visually impaired children. As already studied, video games can bring several beneficial characteristics to the person who practices them, in the research demonstrated we realized that a little more than $65 \%$ see viability in the use of playful activities using audio games in Brazilian elementary school, once it can be worked on audio games as in the video games, providing games that can add the playful feeling to the individual, in view of the acceptance of the external public that the playable technology can increase a good activity for the person and that helps him to develop even with an existing disability. 


\section{CONCLUSION}

The current school lives in an inclusive perspective, where it has to adapt to the needs of all students, whether they are disabled or not. The needs of each one of us go beyond the basic needs, we also need fun, leisure and a teaching offer that goes beyond that traditionally offered. The visually impaired person needs alternatives to the teaching/learning process and the game is an excellent alternative. Audio games are those games that use sound resources to determine the actions and directions that the player needs to take, whether there are graphics or not. Due to its characteristic of using sounds as the main way to guide the user, initiatives like this make us realize that society as a whole is concerned with including people with visual impairments, and playfulness is part of the true inclusion that must exist in society. Thus, we can see that accessibility in digital games provides the visually impaired with access to the fun that these games provide. The infinity of sounds that we can create and record to use in the creation of these games helps in the development of the blind players imagination, and the insertion of a noise of water, wind, rain can prevent the use of the description of these sounds, which makes the most attractive, fun and mostly accessible game. The excess of description is present in many daily activities of the person with visual impairment, and this is a factor that generates discouragement and for a playful activity with the aim of motivating, it is necessary to remove or minimize such descriptions. The playfulness present in digital games adapted for the visually impaired person provides a more enjoyable learning. The act of playing requires a number of cognitive skills from the player, and the development of these cognitive skills, such as attention and working memory, can occur without the player noticing. The analyzed information allowed to identify games that require more than a certain cognitive skill. The study showed partial results on cognitive skills: attention and working memory. Through this, it was possible to identify an increase in the time dedicated to the proposed activities. The students gradually increased the time destined to games and with that, in an inclusive and respectful manner, all individuals in training had greater opportunities of learning and fun. It was also possible to identify a greater amount of information stored in the working memory.

\section{REFERENCES}

“A importância do Ensino Fundamental 1". 'Educa Mais Brasil". Available in: https://www.educamaisbrasil. com.br/etapa-de-formacao-e-series/ensino-fundamental-i. Accessed in: 13/03/2020
Dos Santos, V. S.; "Estratégias de ensino-aprendizagem". 'Brasil Escola'. Available in: https:/educador. brasilescola. uol.com.br/estrategias-ensino. Accessed in: 21/02/2020

Arce, D.; "A importância das atividadeslúdicas para o desenvolvimento da criança". 13/07/2016. Available in: https://www.redecaminhodosaber.com.br/blog/atividades -ludicas/. Accessed in: 13/03/2020

Pereira, L. C. K.; “A inclusão de crianças com deficiência no Brasil". 26/10/2016. Available in: https://revista crescer. globo.com/Colunistas/Lilian-Kuhn/noticia/2016 /10/inclusao-de-criancas-com-deficiencia-no-brasil.html. Accessed in: 14/03/2020

Bruini, E. C; "Educação no Brasil". 'Brasil Escola'. Available in: https://brasilescola.uol.com.br/educacao/educacao-nobrasil.htm. Accessed in: 14/03/2020

"Declaração de Salamanca". Available in: https://www. cascavel.pr.gov.br:444/arquivos/08092010_a_declaraa\% E2\%80\%A1ao_de_salamanca.pdfhttps://www.educabrasi 1.com.br/declaracao-de-salamanca/. Accessed in: 21/02 12020

Acic Floripa; "5 dificuldades que criançascegasenfrentam". 30/01/2017. Available in: https://medium.com/ @acic floripa/5-dificuldades-que-crian $\% \mathrm{C} 3 \% \mathrm{~A} 7 \mathrm{as}-$ cegasenfrentam-89938aefbe81. Accessed in: 14/03/2020

Da Luz, A. F.; Koller, F. S.; Lima, J. D.; Lafraia, L. M.; "5 motivos para apoiar o uso de videogames naeducação dos filhos". 07/11/2017. Available in: https://www. semprefamilia.com.br/educacao-dos-filhos/5-motivospara-apoiar-o-uso-de-videogames-na-educacao-dosfilhos/. Accessed in: 20/02/2020

Santomauro, B.; "14 jogos que contribuem para a aprendizagem". 01/03/2013. Available in: https:// novaescola. org.br/conteudo/3582/14-jogos-que-contri buem-para-a-aprendizagem. Accessed in: 21/02/2020

"A Blind Legend - Seja um grandecavaleiro e salve suaa madanesteaudiogame". 15/09/2014. Available in: http://jogandoascegas.com.br/blind-legend-seja-umgrande-cavaleiro-e-salve-sua-amada-neste-audio-game/. Accessed in: 22/02/2020

Ferreira, L.; "Jogosvirtuaismelhoram a atenção e memo riasegundoespecialistas". 08/02/2011. Available in: https://www.uol.com.br/tilt/ultimas-noticias/redacao/ 2011/02/08/jogos-virtuais-melhoram-a-atencao-e-amemoria-segundo-especialistas.htm. Accessed in 14/03/ 2020 